\title{
INSTRUMEN TES KECERDASAN LOGIKA-MATEMATIKA UNTUK ANAK USIA DINI
}

\author{
NYOMAN UTARI DEWI INDRIATI
}

\author{
PAUD PPS Universitas Negeri Jakarta \\ Jl. Rawamangun Muka, Jakarta Timur. E-mail: utari.utaridewi.dewi9@gmail.com
}

\begin{abstract}
This study aims to produce an instrument Logical-mathematical intelligence test in early childhood are valid and reliable. This research was conducted in six kindergartens in Jakarta. The method used in this research is the development method adapted from Dick-Carey instructional models and models of development Djaali-Moeljono. There are three main stages in the development of this instrument to obtain instruments finals, namely: (1) Phase Introduction namely: identify problems and conduct studies theories (2) phase of product development, including designing constructs measured variables based on the theory, development dimension, indicators and grains instruments, testing the validity by experts and panels, a revised instrument panel based on expert input and analysis and reliability testing results. (3) Implementation Phase includes: field trials, conducted empirical test, a revision clause instrument, obtaining final instrument and establishing guidelines for administration and scoring. Test instruments resulting from this research is the instruction sheet, item pictures and marking sheet. The tests showed that whole grains have a significant level of $<0.05$, with the value of reliability coefficient of 0.856 . The results showed that the test instrument LogicalMathematical intelligence fit for use.
\end{abstract}

Keywords: research development, test, Logical-Mathematical intelligence

\begin{abstract}
Abstrak: Penelitian ini bertujuan untuk menghasilkan instrumen tes kecerdasan logikamatematika pada anak usia dini yang valid dan reliabel. Penelitian ini dilakukan di enam sekolah TK di wilayah DKI Jakarta. Metode yang digunakan pada penelitian ini adalah metode pengembangan yang diadaptasi dari model instruksional Dick-Carey dan model pengembangan Djaali-Moeljono. Ada tiga tahapan utama dalam pengembangan instrumen ini hingga memperoleh instrumen final, yaitu: (1) Tahap Pendahuluan yaitu : mengidentifikasi masalah dan melakukan kajian teori-teori (2) Tahap Pengembangan produk, meliputi penyusunan konstruk variabel yang diukur berdasarkan teori, pengembangan dimensi, indikator dan butir instrumen, pengujian validitas oleh pakar dan panel, revisi instrumen berdasarkan masukan pakar dan panel, analisis hasil dan uji reliabilitas. (3) Tahap Implementasi meliputi : Uji coba lapangan, melakukan uji empiris, revisi butir instrumen, memperoleh instrumen final dan penyusunan pedoman administrasi dan penskoran. Instrumen tes yang dihasilkan dari penelitian ini adalah lembar instruksi, butir soal gambar dan lembar penilaian. Hasil validasi menunjukkan bahwa seluruh butir memiliki taraf signifikan $<0,05$, dengan nilai koefisien reliabilitas 0,856 . Hasil tersebut menunjukkan bahwa instrumen tes kecerdasan Logika-Matematika layak untuk digunakan.
\end{abstract}

Kata kunci: penelitian pengembangan, tes, kecerdasan Logika Matematik

Saat ini masih banyak orang yang beranggapan bahwa anak yang cerdas adalah anak yang pandai matematika, dalam hal ini dilihat dari nilai akademis yang diperoleh. Maka pendidik atau orang tua memaksakan 
anak untuk belajar matematika sedemikian rupa sejak usia dini dengan tujuan agar anak mampu menyelesaikan soal-soal matematika yang diberikan dengan mendapat nilai bagus dan memperoleh predikat cerdas. Mengajarkan matematika pada anak usia dini tidaklah mudah karena selain mengenalkan bilangan dan angka kita juga dituntut untuk mengembangkan logika berpikir anak tanpa membuat anak terpaksa. Selama ini di Taman Kanak-kanak matematika dikenalkan dengan cara mengerjakan soal-soal hitungan seperti pada tingkat Sekolah Dasar kelas awal, hal ini menyebabkan anak merasa terbebani dan kesulitan untuk mengerti tentang matematika, bahkan matematika menjadi hal yang menakutkan bagi anak-anak. Bahkan untuk mengukur kemampuan logikamatematika, anak harus mengerjakan soal-soal hitungan konkret yang tersruktur.

Untuk mengukur kemampuan anak dan mengukur tercapainya program pembelajaran yang telah dilaksanakan adalah dengan penilaian. Kegiatan pengukuran dan penilaian adalah merupakan upaya pengumpulan informasi yang benar tentang pencapaian belajar para siswa. Informasi tersebut selanjutnya akan digunakan sebagai dasar dalam pengambilan keputusan-keputusan kebijaksanaan baik secara lokal maupun nasional. Agar dapat diperoleh informasi yang benar dan akurat dimana sangat besar pengaruhnya dalam pengambilan keputusan, maka diperlukan alat-alat pengukur yang baik yaitu yang memenuhi syarat-syarat baik kesahihannya/validitas maupun kehandalannya/reliabilitas.

Pemantauan secara holistik terhadap perkembangan kemampuan dasar maupun kemampuan pembiasaan anak usia dini, terutama di lembaga PAUD formal seperti Taman KanakKanak (TK) dan Raudlatul Athfal (RA), haruslah terintegrasikan dengan proses pembelajaran melalui bermain. Oleh karenanya, pendidik/guru TK selain mempersiapkan Satuan Kegiatan Harian (SKH) untuk memandu proses pembelajaran, seharusnya mempersiapkan juga berbagai alat dan 
$\cos$

untuk

melakukan

serta penyusunan pedoman

penilaian/asesmen

terhadap

perkembangan kemampuan anak dalam

pembelajaran

logikamatematika tersebut.

Dari hasil observasi awal ditemukan kenyataan bahwa ada ketidaksesuaian antara standar isi, standar proses dan standar evaluasi/penilaian, sehingga akan mengakibatkan kesenjangan hasil penilaian pada masing-masing sekolah khususnya dalam kecerdasan logikamatematika, yaitu dalam perhitungan matematis atau mengolah angka, berfikir logis dan pemecahan masalah. Hal ini dikarenakan belum adanya instrumen yang baku pada masingmasing tahapan usia dalam pembelajaran. Kemampuan dan kreativitas guru pun tidak sama dalam membuat instrumen.

Pengembangan instrumen kecerdasan dimaksudkan untuk mendapatkan instrumen baku, yaitu instrumen yang dikembangkan secara empiris melalui beberapa pengujian. Proses pembakuan instrumen adalah pembuatan, pengujian, dan revisi, administrasi dan penskoran. Sehingga pembakuan dilakukan dengan memperbaiki isi instrumen, pengadministrasian, dan penskoran, sehingga didapatkan tingkat keakuratan instrumen yang signifikan (Soeprijanto 2010:121). Proses ini melalui beberapa tahapan instruksi yang menekankan pada bagaimana instrumen dapat mengukur dan memberikan hasil yang dapat mewakili keadaan di lapangan.

Menurut Djaali dan Pudji Muljono (Djaali 2008:60-62) langkahlangkah pengembangan instrumen adalah sebagai berikut: 1) merumuskan konstruk berdasarkan sintesis dan teori-teori yang dikaji, 2) dari konstruk dikembangkan dimensi dan indikator variabel yang hendak diukur, 3) membuat kisi-kisi instrumen dalam bentuk tabel spesifikasi yang memuat dimensi, indikator, nomor butir dan jumlah butir, 4) menetapkan besaran atau parameter dalam suatu rentangan kontinum dari suatu kutub ke kutub lain yang berlawanan, 5) menulis butir-butir instrumen dalam bentuk 
pertanyaan dan pernyataan, 6) instrumen penelitian agar dapat melakukan proses validasi, 7) dinyatakan memiliki kualitas yang melakukan validasi teoritik, 8) baik yaitu validitas, reliabilitas, merevisi berdasarkan hasil panel, 9) dan praktikabilitas. Aiken Lewis melakukan penggandaan instrumen (Budi Susetyo 2015:112) untuk uji coba, 10) uji coba di mengatakan, lapangan yang merupakan validasi "validity of a test has been defined as empirik, 11) pengujian validasi empiris dengan menggunakan kriteria internal dan eksternal, 12) berdasarkan kriteria diperoleh kesimpulan mengenai valid tidaknya sebuah butir atau perangkat instrumen tersebut, 13) berdasarkan analisis butir, butir-butir yang tidak valid dikeluarkan atau diperbaiki, butirbutir yang valid dirakit kembali, 14) menghitung koefisien reabilitas, 15) perakitan kembali butir-butir yang valid untuk dijadikan instrumen. Dalam penyusunan suatu alat ukur perlu diperhatikan kejelasan konsep atau teori yang menjadi landasan kerja pengukuran, melakukan identifikasi dan definisi objek ukur, kesesuaian alat ukur dengan spesifikasi objek ukur.

\section{Validitas}

$$
\begin{aligned}
\text { Kriteria } & \text { pokok yang } \\
\text { harus dipenuhi } & \text { oleh suatu }
\end{aligned}
$$

the extent to which the test measures what it was designed to measure" yang dapat diartikan bahwa kesahihan dibatasi sebagai tingkat kemampuan suatu instrumen untuk mengungkap sesuatu yang menjadi sasaran pokok pengukuran. Validitas dapat diartikan sejauh mana hasil pengukuran dapat diinterpretasikan sebagai cerminan sasaran ukur yang berupa kemampuan, karakteristik, atau tingkah laku yang diukur melalui alat ukur yang tepat.

Nitko (Nitko 2001:36) menggambarkan validitas sebagai berikut, "Validity is the soundness of your interpretation and uses of student's assessment result. Validity emphasizes the results you interpret, not the instrument or procedures itself" yang diartikan bahwa validitas merupakan kekuatan pada interpretasi yang digunakan dalam hasil penilaian. Validitas 
menekankan pada hasil interpretasi, bukan pada instrumen atau prosedurnya. Untuk mengatakan bahwa hasil penilaian itu valid, kita harus membuktikan bahwa penafsiran dan penggunaan instrumen adalah sesuai.

\section{Reliabilitas}

Suryabrata (Suryabrata 2010:60) berpendapat bahwa reliabilitas instrumen merujuk kepada konsistensi hasil perekaman data (pengukuran) kalau instrumen itu digunakan oleh orang atau kelompok orang yang sama dalam waktu berlainan, atau kalau instrumen itu digunakan oleh orang atau kelompok orang yang berbeda dalam waktu yang sama atau dalam waktu yang berlainan. Reliabilitas merujuk pada ketetapan/keajegan alat tersebut dalam menilai apa yang diinginkan, artinya kapanpun alat tersebut digunakan akan memberikan hasil yang relatif sama.

\section{Kecerdasan Logika Matematika}

Howard Earl Gardner yang juga adalah seorang profesor bidang pendidikan di Harvard University berpendapat bahwa an intelligence as the ability to solve problems or to create products that are valued within one or more cultural settings." (Gardner 1983:60-61). Gardner tidak memandang kecerdasan manusia berdasarkan skor semata dan bukan sesuatu yang dapat dilihat atau dihitung, melainkan dengan ukuran kemampuan yang diuraikan sebagai berikut: (1) kemampuan untuk menyelesaikan masalah, kemampuan untuk menghasilkan persoalan-persoalan baru untuk dipecahkan, (3) kemampuan untuk menciptakan sesuatu atau memberikan penghargaan untuk budaya seseorang. Selain itu, dengan teori kecerdasan majemuk Gardner menyatakan ada delapan tipe kecerdasan yaitu kecerdasan verbal, logis-matematis, spasial, kinestetik tubuh, musik, interpersonal, intrapersonal dan naturalistik. Menurutnya, setiap manusia memiliki semua tipe

kecerdasan ini dengan taraf berbedabeda.
Armstrong
(Armstrong mendefinisikan 2009:6) 
kecerdasan logikamatematika sebagai berikut:

\begin{abstract}
"Logical-mathematical
Intelligence is the capacity to use numbers effectively and to reason well. This intelligence includes sensitivity to logical patterns and relationships, statements and propositions, functions, and other related abstractions. The kinds of processes used in the service of logical-mathematical intelligence include categorization, classification, inference, generalization, calculation, and hypothesis testing."
\end{abstract}

Kemampuan ini, meliputi kemampuan menyelesaikan masalah, mengembangkan masalah, dan menciptakan sesuatu dengan angka dan penalaran. Menurut Armstrong, anak-anak yang memiliki kecerdasan ini terlihat pada keunggulan dalam hal kemampuan menjelaskan masalah secara logis, merancang eksperimen untuk menguji hal-hal yang tidak dimengerti, bermain teka-teki logika (seperti rubrik atau kubus), menyusun berdasar hirarki atau kategori dan memahami sebab akibat.

Sejalan dengan pendapat di atas Wong (Wong 2009:26) menambahkan bahwa logicalmathematical intelligence is the ability to use logic, problem solving, analysis, and mathematical calculations effectively. Seseorang dengan kecerdasan ini secara efektif mampu menggunakan logika, pemecahan masalah, analisa dan perhitungan matematika. Kekhususan kecerdasan ini mencakup kemampuan dalam menggunakan penalaran, identifikasi pola, berpikir konkret dan abstrak, memahami dan menggunakan simbol, menyukai perhitungan angka yang rumit, menggunakan cara berpikir yang sistematis, logis, teknik pemecahan masalah yang baik dan menggunakan metode ilmiah untuk mengukur, membuat praduga, menguji, meneliti dan menunjukkan hasil.

$$
\text { Penny Deiner (Deiner }
$$
2013:341) mengatakan "Scientific reasoning, a love for abstraction, 
understanding of numerical patterns and problems and an interest in mathematical operations characterize logical-mathematical intelligence" yang diartikan bahwa berpikir ilmiah, menyukai sesuatu yang abstrak, memahami pola dan masalah numerik, minat pada operasional matematik menjadi karakteristik kecerdasan logikamatematika. Anak-anak yang memiliki kecerdasan ini akan menggunakan logika, deduksi, penalaran dan sebagai seorang yang mampu memecahkan masalah dengan baik. Mereka menyukai eksperimen, berhitung, manipulasi angka, kategorisasi dan permainan komputer.

\section{Konstruk, Dimensi dan Indikator}

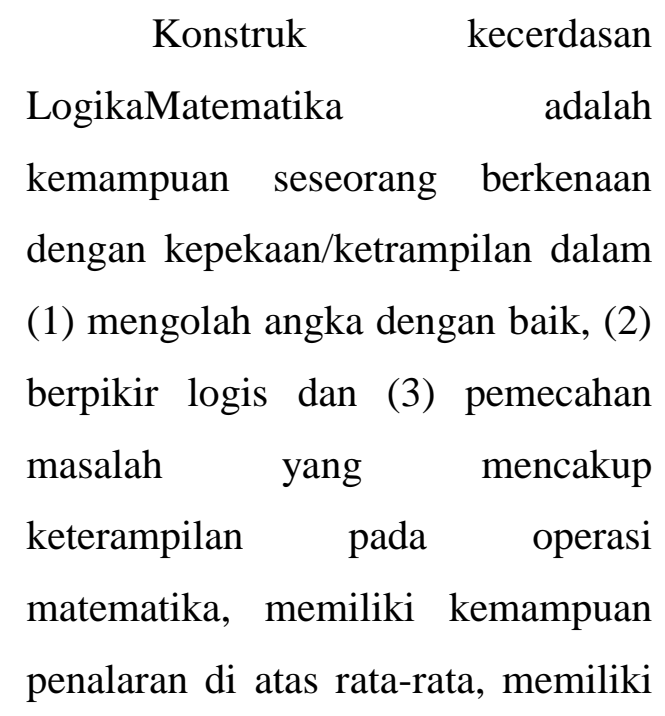

pemahaman terhadap konsep logis, memahami pola abstrak dan numerik, dapat menyusun strategi dalam memecahkan masalah.

Indikator dari dimensi perhitungan matematika yaitu anak mampu: (1) mengenal urutan bilangan, membilang/menghitung banyaknya benda, (3) mengenal konsep tambah dan kurang, (4) membandingkan jumlah benda, dan (5) mengukur benda/obyek.

$$
\text { Indikator dari dimensi }
$$
berpikir logis yaitu anak mampu: (1) memanipulasi materi/obyek (berpikir simbolik), (2) memahami konsep geometri, (3) memahami hubungan sebab-kibat dengan mudah, dan (4) memahami hubungan pola/urutan kejadian.

\footnotetext{
Indikator dari dimensi pemecahan masalah, yaitu anak mampu: (1) mengidentifikasi masalah dengan mudah, mengklasifikasikan masalah dengan baik, (3) memecahkan misteri dan teka-teki secara sistematis,
} 
(4) membuat rencana atau estimasi.

\section{METODE}

Penelitian ini merupakan penelitian pengembangan yang mengadopsi model instruksional Dick-Carey dan model pengembangan DjaaliMoeljono karena kedua model ini memiliki tahapan yang detail dan jelas, sehingga kami harapkan dengan mengikuti prosedur kedua model tersebut instrumen yang dihasilkan dapat optimal. Adapun proses pengembangan instrumen kecerdasan logika-matematika ini melalui tahaptahap berikut: (1) Tahap Pendahuluan yaitu : mengidentifikasi masalah dan melakukan kajian teoriteori (2) Tahap Pengembangan Produk, meliputi peyusunan konstruk variabel yang diukur berdasarkan teori, pengembangan dimensi, indikator dan butir instrumen, pengujian validitas oleh pakar dan panel, revisi instrumen berdasarkan masukan pakar dan panel, analisis hasil dan uji reliabilitas. (3) Tahap Implementasi meliputi : Uji coba lapangan, melakukan uji empiris, revisi butir instrumen, memperoleh instrumen final dan penyusunan pedoman administrasi dan penskoran.
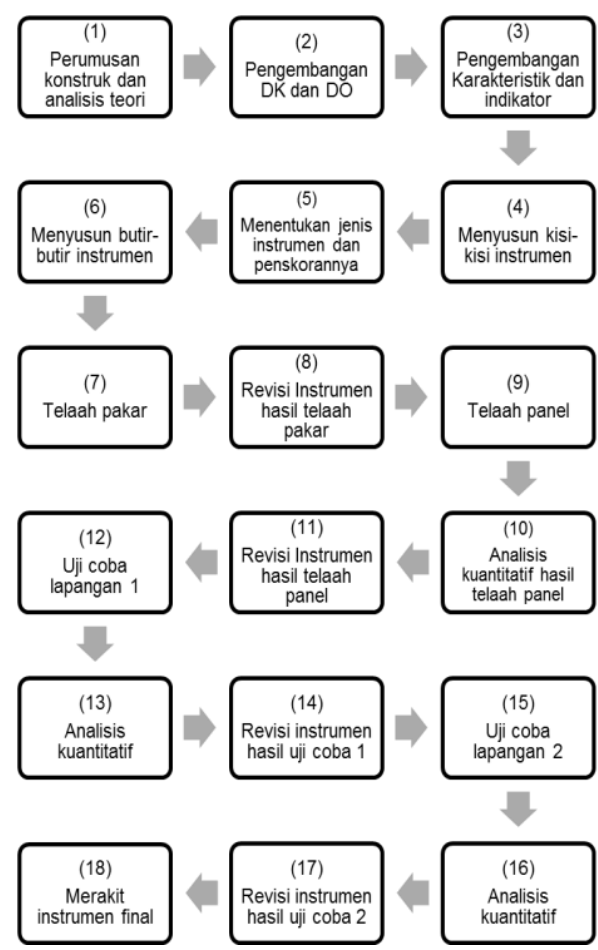

Gambar $\quad 3.1 \quad$ Langkah-Langkah Pengembangan Instrumen Kecerdasan Logika Matematika untuk Anak Usia Dini

\section{Metode Pengujian Instrumen}

Instrumen yang valid adalah instrumen yang dapat digunakan untuk mengukur apa yang hendak diukur, sedangkan instrumen yeng reliabel adalah instrumen yang bisa digunakan beberapa kali untuk mengukur 
obyek yang sama dan akan menghasilkan data yang sama.

Pengujian validitas dan reliabilitas instrumen kecerdasan logika-matematika anak usia dini juga menggunakan rumusan dan langkahlangkah yang meliputi: uji validitas yang meliputi validitas isi (konstruk) dan validitas empiris, dan pengujian reliabilitas.

Setelah terbentuknya butir pernyataan yang dibuat berdasarkan kisi-kisi instrumen, maka yang dilakukan berikutnya adalah melakukan validitas berkaitan dengan konstruk. Hal ini dimaksudkan apakah butir-butir yang dibuat mencerminkan indikator yang dimaksud. Validasi ini merupakan pengujian terhadap butir pernyataan dengan analisis rasional melalui professional judgment atau kesepakatan pakar (Azwar 2013:52). Validasi konstruk dalam penelitian ini melibatkan 4 (empat) orang pakar yang memiliki kemampuan dalam bidang pengukuran dan evaluasi, kecerdasan logika-matematika, dan pendidikan anak usia dini.
Setelah divalidasi oleh beberapa panelis, instrumen kecerdasan logika-matematika diujicobakan. Uji validitas empiris dilakukan dengan mengujicobakan instrumen kepada responden. Untuk menentukan validitas setiap butir dilakukan dengan menganalisis data hasil ujicoba. Hasil ujicoba dianalisis untuk menentukan validitas konstruk instrumen dengan menggunakan analisis korelasi point biserial dan selanjutnya dihitung nilai koefisien reliabilitasnya untuk menunjukkan sejauh mana suatu alat ukur dapat dipercaya atau dapat diandalkan.

Selain itu juga perlu dihitung tingkat kesukaran suatu butir. Kebaikan suatu tes juga akan ditentukan oleh tingkat kesukaran masing-masing butir atau item. Item yang terlalu sukar atau item yang terlalu mudah merupakan hal yang tidak baik. Bilangan yang menunjukkan sukar dan mudahnya sesuatu soal disebut indeks kesukaran (difficulty index). Besarnya indeks kesukaran antara 0,00 sampai dengan 1,00 (Arikunto 2012:223). Semakin besar bilangan indeksnya maka butir 
atau item semakin mudah begitu sebaliknya semakin kecil bilangan indeksnya maka butir soal atau item semakin sukar. Tingkat kesukaran suatu butir atau item tidak berlaku universal, tetapi hanya untuk kelompok yang dikenai oleh tes yang dimaksudkan.

Daya pembeda soal adalah kemampuan suatu soal untuk membedakan antara siswa yang pandai (berkemampuan tinggi) dengan siswa yang bodoh (berkemampuan rendah). (Arikunto 2013:226). Daya pembeda dari suatu item dinyatakan dalam bilangan desimal dan berkisar antara 0,00 sampai 1,00. Kriterianya sebagai berikut: $0.40-1.00$ = sangat baik

$0.30-0.39=$ diterima $/$ diperbaiki

$0.20-0.29=$ diperbaiki

$0.00-0.19=$ ditolak

\section{HASIL DAN PEMBAHASAN}

Penilaian oleh pakar dan panelis dilakukan dengan tujuan untuk mengetahui validitas konstruk dari instrumen atau perangkat tes yang dikembangkan. Hal pokok yang akan dinilai oleh pakar dan panelis adalah:

a. Petunjuk pengisian instrumen,

b. Penggunaan bahasa yang sesuai dengan Ejaan Yang

Disempurnakan (EYD)

c. Kesesuaian dengan karakteristik anak usia 5-6 tahun

d. Kesesuaian indikator yang akan dikembangkan terhadap konsep atau konstruk yang digunakan.

Berdasarkan penilaian pakar, secara umum indikator yang disusun dinilai sudah mewakili dimensi dari konstruk kecerdasan logikamatematika anak usia 5-6 tahun. Indikator-indikator yang disusun merupakan representasi dari penjabaran dimensi dari konstruk yang telah disefinisikan. Dengan kata lain konstruksi butir sudah sesuai dengan indikatornya.

\section{Validitas Empirik Tahap Pertama}

Pada uji coba tahap pertama instrumen yang digunakan adalah instrumen yang telah melewati tahapan analisis kualitatif hasil oleh pakar serta analisis validitas dan reliabilitas oleh panelis sehingga diperoleh instrumen sebanyak 28 butir dan selanjutnya di 
uji cobakan kepada 30 (tigapuluh) siswa kelompok B di 3 (tiga) sekolah. Dan diperoleh hasil bahwa butir soal nomor 13 mempunyai nilai $r_{\text {hitung }}$ 0,086 dan butir nomor 20 mempunyai nilai $r_{\text {hitung }} 0,197$ dimana $r_{\text {hitung }}$ lebih kecil dari 0,2 yang berarti kedua butir soal tersebut dinyatakan tidak valid dan untuk selanjutnya didrop atau dihilangkan. Setelah pengujian validitas maka tahap selanjutnya adalah melakukan uji reliabilitas. Berdasarkan nilai Cronbach's Alpha pada tabel Reliability Statistics diperoleh nilai $\alpha=\mathbf{0 . 8 7 7}$. Nilai koefisien reliabilitas tersebut dikatakan sangat tinggi, sehingga instrumen bisa digunakan sebagai alat ukur yang handal. Taraf kesukaran butir yang ditunjukkan oleh nilai Mean pada tabel statistcs menunjukkan bahwa semua butir soal memperoleh nilai > 0,70, dengan demikian seluruh butir soal mempunyai tingkat kesukaran: mudah. Sedangkan daya pembeda menunjukkan bahwa butir nomor 13 dan no 20 ditolak, butir no 12 dan 22 direvisi.

\section{Validitas Empirik Tahap Kedua}

Pada uji coba tahap kedua yang dilakukan pada tanggal 12-22 Juni 2016, instrumen yang digunakan adalah instrumen hasil analisis validitas dan reliabilitas uji empiris tahap pertama sebanyak 26 butir dan selanjutnya di uji cobakan kepada 50 (limapuluh) siswa kelompok B di 3 (tiga) sekolah. Hasil yang diperoleh adalah semua butir dinyatakan valid dengan koefisien reliabilitas 0,856 . Taraf kesukaran menunjukkan bahwa sebagian butir soal pada kriteria mudah dan sebagian lagi pada kriteria sedang. Daya pembeda menunjukkan bahwa seluruh butir soal dinyatakan baik.

\section{KESIMPULAN}

Dari hasil penelitian, diperoleh penilaian pakar (expert judgement), secara umum indikator yang disusun dinilai sudah mewakili dimensi dari konstruk kecerdasan logikamatematika anak usia 5-6 tahun. Indikator-indikator yang disusun merupakan representasi dari penjabaran dimensi dari konstruk yang telah disefinisikan. Dengan kata 
lain terdapat kesesuaian antara konstruksi butir dengan indikatornya. Hasil dari validasi ini menyatakan bahwa instrumen yang dikembangkan dapat diterapkan di program PAUD dengan kategori sangat baik.

Implikasi dari hasil pengembangan instrumen kecerdasan logikamatematika untuk anak usia 56 tahun antara lain:

1. Selama ini di Taman Kanakkanak matematika dikenalkan dengan cara mengerjakan soalsoal hitungan seperti pada tingkat Sekolah Dasar kelas awal dengan memberikan soal-soal hitungan konkret yang tersruktur., hal ini menyebabkan anak merasa terbebani dan kesulitan untuk mengerti tentang matematika.

2. Pendidik atau orang tua memaksakan anak untuk belajar matematika sedemikian rupa sejak usia dini dengan tujuan agar anak mampu menyelesaikan soal-soal matematika yang diberikan dengan mendapat nilai bagus dan memperoleh predikat cerdas.
3. Mengajarkan matematika pada anak usia dini tidaklah mudah karena selain mengenalkan bilangan dan angka kita juga dituntut untuk mengembangkan logika berpikir anak tanpa membuat anak terpaksa.

\section{SARAN}

1. Kepada penyelenggara Pendidikan Anak Usia Dini hendaknya menggunakan instrumen yang dikembangkan untuk mengukur kecerdasan Logika-Matematika sesuai dengan usia dan perkembangan anak serta dilaksanakan dalam suasana santai agar anak tidak bosan.

2. Pengembangan instrumen ini lebih dimantapkan lagi oleh guru dan peneliti, dan diuji pada sample yang lebih besar di beberapa cakupan wilayah untuk mendapatkan kesahihan dan keterandalan yang lebih komperhensif. 


\section{DAFTAR PUSTAKA}

Arikunto, Suharsimi. Dasar- Dasar Evaluasi Pendidikan, Edisi 2. Jakarta : Bumi Aksara, 2012.

Armstrong, Thomas.

Multiple Intelligences In

The Classroom, 3th Ed.

Virginia: ASCD, 2009.

Azwar, Saifuddin. Reliabilitas dan Validitas. Yogyakarta:

Pustaka Pelajar, 2013.

Deiner, Penny L. Inclusive Early

Childhood Education

: Development, Resource and Practice, $\sigma^{\text {th }} \quad E d$.

USA : Wadsworth, 2013.

Djaali, dan Pudji Muljono, Pengukuran Dalam Bidang Pendidikan. Jakarta: PT.

Grasindo, 2008.

Gardner, Howard. Frame Of Mind :

The Theory of Multiple Intelligences. New York : Basic Books, 1983.

Nitko, Anthony J., Educational Assessment of Students, $3^{\text {th }}$ $E d$. New Jersey: Prentice Hall, Inc, 2001.

Soeprijanto, Pengukuran Kinerja

Guru Praktek Kejuruan:

Konsep dan Teknik

Pengembangan Instrumen.

Jakarta: CV.

Tursina, 2010.
Walter, Dick, Carey, L., \& Carey, J, O, The Systematic Design of Instruction, $2^{\text {th }} \quad E d$. USA: Foresman \& Co., 1985.

Wong, Linda. Essential Study Skill, $6^{\text {th }}$ Ed. New York : Houghton Mifflin Company, 2009. 